\section{Mammalian yolk sac - an alternative source of stem cells}

\section{Saco vitelino de mamíferos - uma fonte alternativa de células- tronco}

Priscilla Avelino Ferreira Pinto1* (D), Vitória Mattos Pereira² (D), Lina Castelo Branco Motta ${ }^{3}$ (D), Matheus Ferreira de Almeida² (D), Tiago Gonçalves dos Santos ${ }^{2}$ (D), Vanessa Cristina Oliveira ${ }^{4}$ (D), Luciana Cristina Machado ${ }^{4}$ (1) \& Carlos Eduardo Ambrósio 5 (1)

Physiotherapist, MSc, Departamento de Cirurgia, Faculdade de Medicina Veterinária e Zootecnia, Universidade de São Paulo (USP), São Paulo, SP, Brazil

¿Undergaduate in Veterinary Medicine, Departamento de Medicina Veterinária, Faculdade de Zootecnia e Engenharia de Alimentos, USP, Pirassununga, São Paulo, Brazil

${ }^{3}$ Biologist, MSc, Criocord - Banco de Sangue de Cordão Umbilical e Placentário, Fortaleza, Ceará, Brazil

${ }^{4}$ Biologist, DSc, Departamento de Medicina Veterinária, Faculdade de Zootecnia e Engenharia de Alimentos, USP, Pirassununga, São Paulo, Brazil

${ }^{5}$ Veterinarian, DSc, Departamento de Medicina Veterinária, Faculdade de Zootecnia e Engenharia de Alimentos, USP, Pirassununga, São Paulo, Brazil

\begin{abstract}
Fetal tissue-derived stem cells have been the subject of several studies. Among them, the yolk sac (YS) nourishes the embryo, synthesizes proteins and vitamins, and is the first hematopoietic site of the embryo. Stem cells derived from the YS can benefit several animal species as therapies aimed at tissue regeneration and immunological diseases. This review aims to describe the development, function, and possible dysfunctions of YS in different species, and consolidate the findings presented in the literature on the isolation, culture, and application of YS-derived stem cells from different mammals in regenerative medicine. Hematopoietic and mesenchymal stem cells have been previously investigated in the YS of different mammals; however, the culture media and isolation protocols differ between species. To date, no studies have been conducted using stem cells derived from the YS for cell therapy. Nevertheless, several domestic mammals have shown cellular markers characteristic of mesenchymal stem cells derived from the YS.
\end{abstract}

Keywords: mesenchymal stem cells, hematopoietic stem cells, placenta development, fetal membranes.

\section{Resumo}

As células-tronco derivadas dos tecidos fetais têm sido objeto de vários estudos, entre elas, o saco vitelino (SV) tem a função de nutrir o embrião, sintetizar proteínas e vitaminas, sendo também o primeiro sítio hematopoiético do embrião. Além disso, o estudo de células tronco derivadas do saco vitelino favorece diversas espécies animais, tanto para terapias que buscam a regeneração de tecidos quanto para doenças imunológicas. Assim, esta revisão tem como objetivo descrever o desenvolvimento, função e possíveis disfunções do SV em diferentes espécies de mamíferos, bem como agrupar os resultados já obtidos na literatura sobre o isolamento, cultivo e aplicação de células tronco derivadas do SV. Sabe-se que o saco vitelino apresenta células tronco hematopoiéticas, além da presença de células-tronco mesenquimais em diferentes espécies, entretanto, os meios de cultura e os protocolos de isolamento diferem entre as espécies. Até o momento, nenhum estudo foi encontrado usando células tronco derivadas do saco vitelino para terapia celular, no entanto, vários mamíferos domésticos mostraram marcadores celulares característicos de células tronco mesenquimais derivadas do saco vitelino.

Palavras-chave: células-tronco mesenquimais, células-tronco hematopoéticas, desenvolvimento placentário, membranas fetais.

\section{Introduction}

The placenta, a highly vascularized organ formed by the fusion of fetal membranes with the endometrium, allows the exchange of oxygen, nutrients, and waste between the fetus and the mother, in addition to being related to immunoprotection and fetal growth (Dzierzak \& Robin, 2010; Myren et al., 2007). Some research has been conducted to elucidate placental development

\section{BJ M}

How to cite: Pinto, P. A. F., Pereira, V. M., Motta, L. C. B., Almeida, M. F., Santos, T. G., Oliveira, V. C., Machado, L. C., \& Ambrósio, C. E. (2021). Mammalian yolk sac - an alternative source of stem cells. Brazilian Journal of Veterinary Medicine, 43, e001221. https://doi.org/10.29374/2527-2179. bjvm001221

Received: April 8, 2021

Accepted: May 11, 2021

\section{*Correspondence}

Priscilla Avelino Ferreira Pinto Laboratório de Cultivo de Células Tronco e Terapia Gênica, Departamento de Medicina Veterinária, Faculdade de Zootecnia e

Engenharia de Alimentos, Universidade de São Paulo - USP

Av. Duque de Caxias Norte, 225, ZMV, Campus da USP

CEP 13635-900 - Pirassununga (SP), Brasil

E-mail: priscillaafp@usp.br 
in different species of mammals and identify cell lines for use in regenerative medicine (Carter \& Enders, 2016; Umezawa et al., 2019; Vanover et al., 2017).

The yolk sac (YS) is one of the four placental membranes present in mammals. It is responsible for the nutrition of the embryo during the first trimester of mammalian pregnancy, i.e., the period when vascular communication has not been established yet (Burton et al., 2002). YS plays an important role in protein transport and synthesis and is involved in the absorption of amino acids (King \& Enders, 1970) and vitamins, which are fundamental to the development of the embryo in the early stages of pregnancy (Brent \& Fawcett, 1998; Zohn \& Sarkar, 2010). It is also the first hematopoietic site of the embryo (Palis \& Yoder, 2001) as demonstrated by the presence of hematopoietic and mesenchymal stem cells (Favaron et al., 2014; Mançanares et al., 2015; Oliveira et al., 2017). YS is also responsible for the production of macrophage progenitors in adult tissue (Stremmel et al., 2018).

Stem cells derived from fetal tissues have been the target of several studies, owing to higher capacity of differentiation and proliferation compared to that of stem cells derived from adult tissues (Bobis et al., 2006). Previous studies on the isolation, culture, and characterization of stem cells from the YS in different species have shown that YS-derived stem cells do not exhibit Major Histocompatibility Complex II (MHC II) expression, allowing greater capacity for histocompatibility. Furthermore, in some species, stem cells are positive for pluripotency markers (Borghesi et al., 2019; Cremonesi et al., 2011; Saulnier et al., 2016). However, stem cells derived from fetal tissues have an advantage over embryonic stem cells as they do not result in teratoma formation (Vanover et al., 2017). Therefore, investigations on fetal membrane-derived stem cells enable tissue regeneration and treatment of immune diseases in several animal species.

Thus, this review aims to describe the development, function, and possible dysfunctions of the YS in different species and consolidate findings regarding the isolation, in vitro culture, and application of YS-derived stem cells in regenerative medicine.

\section{Development function and dysfunction of YS in different species}

The YS is composed of two layers, i.e., the endoderm of the hypoblast and the extraembryonic mesoderm. It is responsible for the primary nutrition of the mammalian embryo (Hafez, 2017), embryonic hematopoiesis, and innate immunity, which includes the formation of "blood islands", the sites responsible for the first erythrocytes (Palis \& Yoder, 2001), progenitors of macrophages (Stremmel et al., 2018), and some B lymphocyte strains (Yamane, 2018). The YS also plays a role in the synthesis, transport, and absorption of proteins and immunoglobulins from the mother (Galdos-Riveros et al., 2012; King \& Enders, 1970). The function of the YS depends on several factors, such as the type of placenta (Figure 1).

Considering the case of epitheliochorial placenta, such as in equine species, the YS plays a fundamental role in the survival of the embryo, as it is responsible for regulating the storage and production of progesterone by the endometrium at the beginning of the embryonic phase. At later stages of pregnancy, the YS fuses with the chorion, giving rise to the vitelline chorion placenta, which is responsible for fetal nutrition during the first three months of pregnancy (Hafez, 2017; Raeside et al., 2004). Similarly, in swine species, the nutrition function occurs until day 15 of embryo development, and important proteins, such as albumin and alpha-fetoprotein, are found in the YS tissue, indicating protein biosynthesis (Tiedemann \& Minuth, 1980).

In contrast, in the cotyledonary placenta, as occurring in ruminants, the YS is present in a transient and ephemeral manner, until day 50-70 of gestation. It is responsible for the secretion of proteins and metabolites that are vital for survival and embryonic development, such as myoinositol that acts as a growth factor (Galdos-Riveros et al., 2012). In contrast to that in humans and other domestic animals, the YS of dogs and cats does not regress during the course of embryonic development. In these species, the YS reaches a prominent size in relation to the embryo after 20 days of gestation, being completely vascularized by vessels derived from the umbilical cord (Miglino et al., 2006). In carnivores, after day 24 of embryonic development, the placental membranes become visibly distinct from each other, with the YS appearing as a red structure connected to the central region of the inverted T-shaped embryo with two long projections that persists until birth (Miglino et al., 2006; Wenceslau et al., 2011). Erythropoiesis-characterized by the production of megakaryocytes and primitive erythrocytes-has also been detected in 

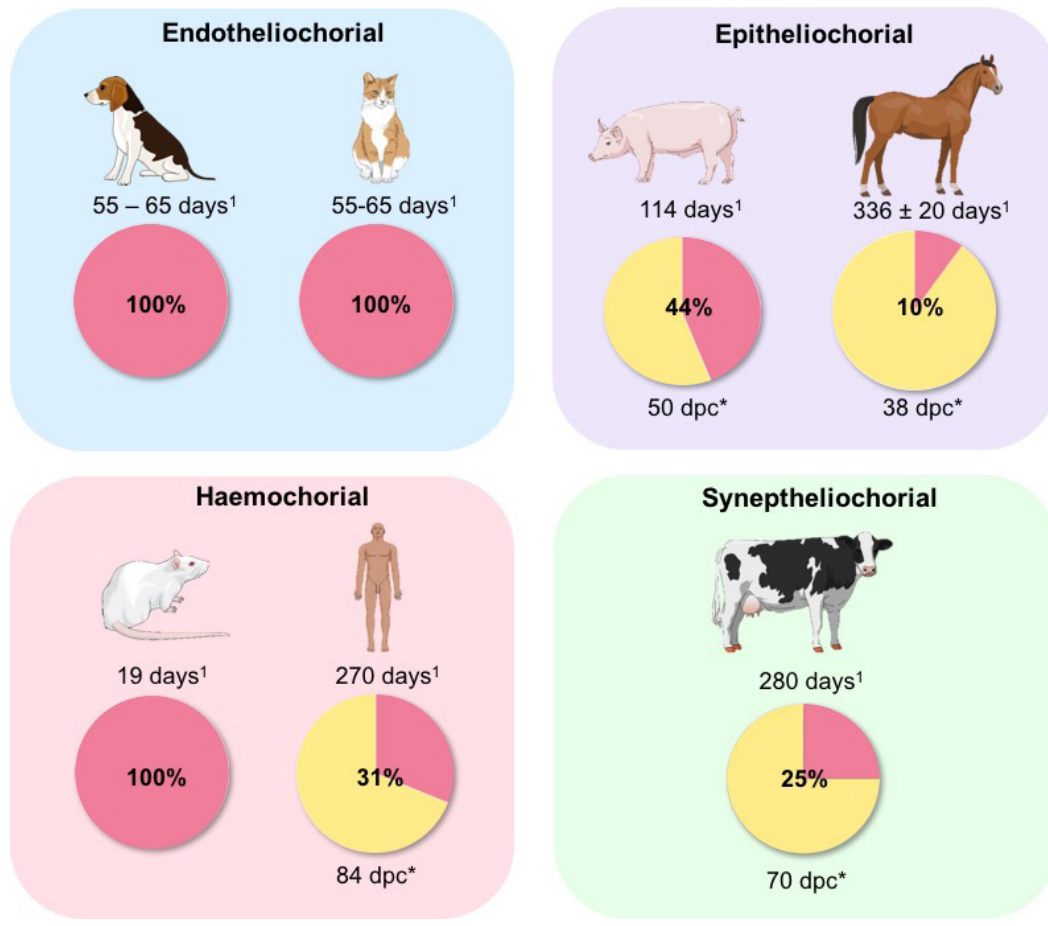

Syneptheliochorial

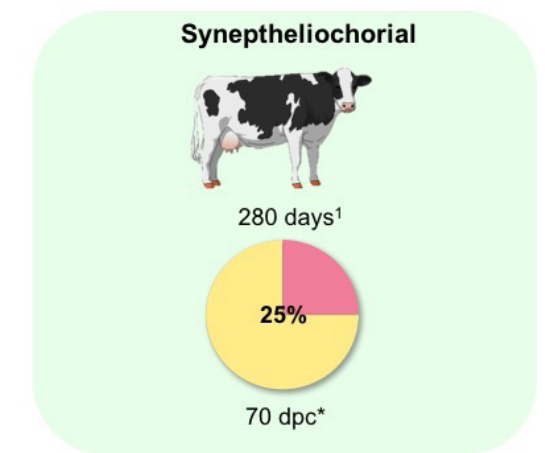

Figure 1. Yolk sac (YS) development and function compared in different species. ${ }^{1}$ gestation time (in days); *YS regression; \%: persistence of YS during pregnancy; dpc: days post coitum.

carnivore YS (Fratini et al., 2016). The carnivore YS is responsible for serum protein biosynthesis before hepatic maturity, a phenomenon fundamental during embryo growth and development (Miglino et al., 2006).

In the hemochorial placenta-present in rodents and humans-the function of YS tissue is elucidated in greater detail owing to the importance of human reproduction and the common use of rodents as animal models for embryological studies. The rodent YS is responsible for the formation of new vessels that enables the transport of gases and nutrients, and production of cholesterol-essential for growth-and growth factors that regulate the growth of vessels and embryonic and placental development; YS is the main source of insulin, which regulates the transfer and synthesis of nutrients (Freyer \& Renfree, 2009). Primordial cells originating from the YS have also been known to be present in the fetal liver (Yamane, 2018). Studies on the mRNA expression profiles have demonstrated that the rodent YS mimics the functions of synthesis and distribution of proteins in the fetal liver before its development. There is also a rhythmic secretion of binding proteins that transport molecules; this process is extremely important for the transport and distribution of tyrosine in the fetus (Thomas et al., 1990).

The role of human YS is similar to that of rodent YS. In addition to hematopoiesis and embryonic nutrition, the YS is also responsible for protein biosynthesis, producing proteins critical to embryonic development, such as albumin, alpha-fetoprotein, and transferrin, and forms a plexus of vessels that aid the distribution of nutrients (Dzierzak \& Robin, 2010; Giacomini et al., 2017; Gulbis et al., 1998). In humans, the YS is related to protein transport and production associated with embryonic growth (Gulbis et al., 1998). In addition, in birds, as there is no maternal-fetal connection, the YS has plays a central role in embryonic nutrition and growth, and has also been associated with the regulation of fetal metabolism through the modulation of thyroid hormones (Seifert, 2014).

A recent study demonstrated the presence of the ATP binding cassette and single solute carrier proteins, which are involved in transporting cholesterol and metals. These transporters are conserved across species, and are present in human, mouse, and chick YS (Lin et al., 2015). Moreover, these transport proteins are associated with multidrug resistance and absorption (Lin et al., 2015).

Furthermore, a correlation has been identified between the health of the YS and the life prospects of the embryo. In cases where the mother has diabetes-characterized by an irregular 
glycemic curve-vasculopathy of the YS is a likely outcome, possibly causing changes in the embryo or even embryonic death (Dong et al., 2016). In addition, the size of YS correlates with the proper development of the embryo (Brent \& Fawcett, 1998), but it is impossible to separate the cause from the effect in vivo. Furthermore, the loss of bovine clones during early embryonic development is associated with abnormal YS development (Mess et al., 2017).

Despite these recent discoveries, there is a lack of understanding regarding the consequences of YS dysfunction and the mechanism by which YS absorbs nutrients. It is also important to emphasize that most pregnancy losses occur in the first months of gestation. Hence, this underestimated structure could be involved in some of the causes.

\section{YS-derived stem cells}

Several studies presented in the literature describe the isolation of stem cells from the YS (Figure 2), to identify cells related to hematopoiesis or the development of the immune system (Bian et al., 2020; Cumano et al., 1993; Sousa et al., 2017; Weiskopf et al., 2016; Zambidis et al., 2005). However, few studies have been conducted to isolate and culture cells for cell therapy (Table 1).

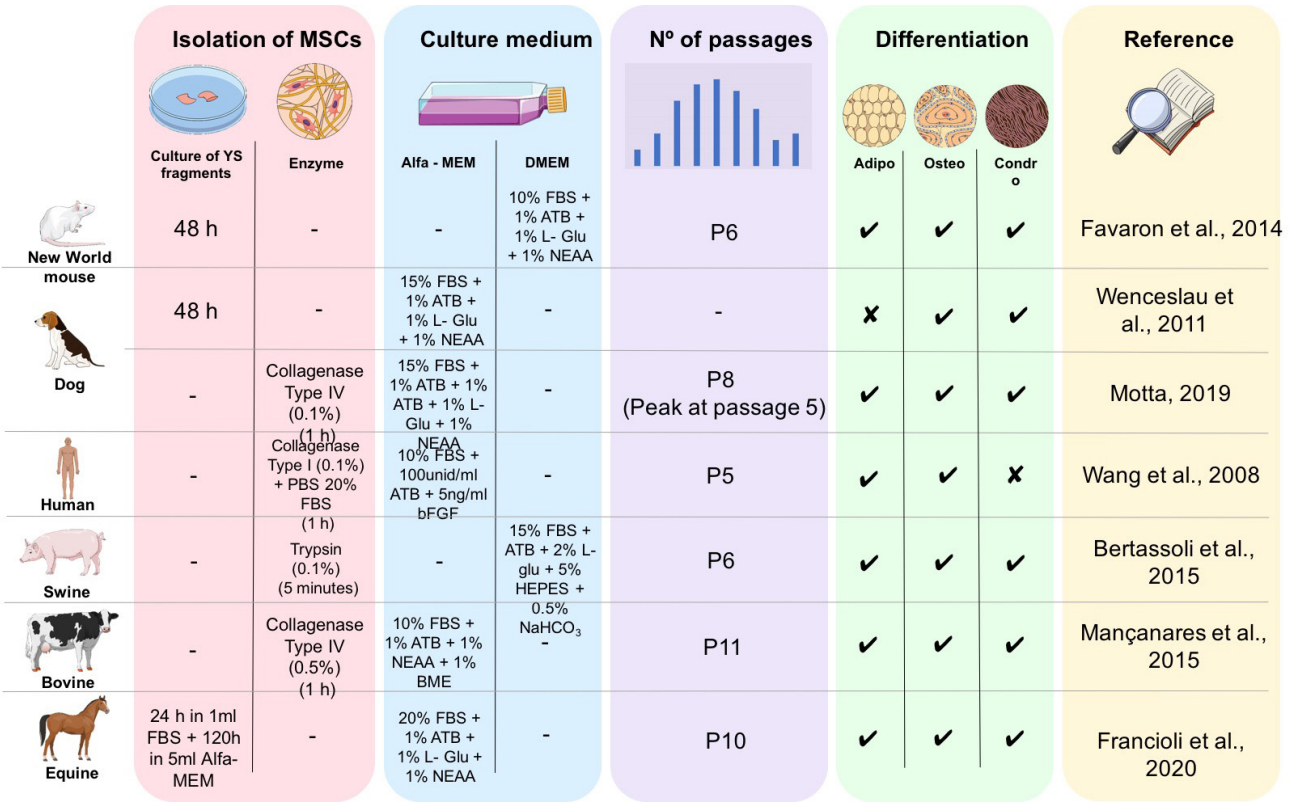

Figure 2. Methodologies applied for the isolation of the mesenchymal stem cells from the yolk sac of different animals. Alfa-MEM: $\alpha$-minimum essential medium; ATB: antibiotic solution; bFGF: beta fibroblast growth factor; BME: beta-mercaptoethanol; DMEM: Dulbecco's Modified Eagle Medium; L-Glu: L-glutamine; NEAA: nonessential amino acids; YS: yolk sac.

Thus, this review analyzes articles in which hematopoietic cells and MSC lines from the YS tissue of different species were cultured and characterized.

\section{YS-derived hematopoietic stem cells (HSCs)}

During the initial development of the embryo, the first blood cells appear in the mesoderm of the YS. In the mesoderm, vascular islands of stem cells are formed, and these primitive multipotent stem cells are later colonized by hemangioblasts. The hemangioblasts can differentiate into either endothelial or hematopoietic cells and renew themselves such that a pool of cells is maintained for the continuous production of all blood cells (Hyttel et al., 2009). This relationship between endothelial cells and hematopoietic cells indicates that they originate from a common precursor, i.e., the hemangioblast (Choi et al., 1998; Hyttel et al., 2009).

The term hemangioblast was most noted when cells from endothelial and hematopoietic lineages were found to share the expression of a number of different genes (Young et al., 1995).

The first blood cells to be formed in the YS are nucleated erythrocytes. These primitiveerythrocytes evolve in a few days and give rise to enucleated erythrocytes that enter the circulation (Mikkola 
Mammalian yolk sac - an alternative source of stem cells

Table 1. Membrane markers of stem cells derived from the yolk sac in different species.

\begin{tabular}{|c|c|c|c|}
\hline Species & Cell line & Cell markers & References \\
\hline \multirow{3}{*}{ Mouse } & & $\mathrm{CD} 45^{+}, \mathrm{CD} 117^{+}$ & Yamasaki et al. (2011) \\
\hline & hematopoietic & $\begin{array}{l}\text { CD44; CD4; Sca-1; } \\
\text { CD45+ }\end{array}$ & $\begin{array}{c}\text { Huang \& Auerbach } \\
\text { (1993) }\end{array}$ \\
\hline & hematopoietic & $\mathrm{CD}{ }^{+}, \mathrm{CD} 34^{+}, \mathrm{CD} 117^{+}$ & Oliveira et al. (2017) \\
\hline Bovine & mesenchymal & $\begin{array}{c}\mathrm{CD}^{+}{ }^{+}, \mathrm{CD}^{\circ} 5^{+}, \mathrm{CD} 79 \\
\mathrm{CD} 44 ; \mathrm{CD} 45\end{array}$ & Mançanares et al. (2015) \\
\hline Canine & mesenchymal & $\begin{array}{l}\text { CD44; , vimentin }{ }^{+} \text {, } \\
\text { nestin+, CD117, CD13; } \\
\text { CD29; CD31; CD90; } \\
\text { CD45; and CD14; } \\
\text { CD146 }\end{array}$ & Wenceslau et al. (2011) \\
\hline Swine & mesenchymal & 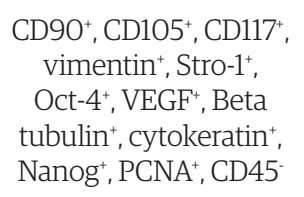 & Bertassoli et al. (2015) \\
\hline Equine & mesenchymal & $\begin{array}{c}\mathrm{CD} 45^{+}, \mathrm{CD}^{2} 4^{+}, \mathrm{CD}_{105^{+}} \\
\mathrm{OCT}^{\prime} / 4^{+}, \mathrm{Nanog}^{+} \\
\text {Stro- } \mathbf{1}^{+}\end{array}$ & Franciolli et al. (2020) \\
\hline New World mouse & mesenchymal & $\begin{array}{c}\mathrm{CD}{ }^{+}, \mathrm{CD} 105^{+}, \mathrm{CD} 3^{+} \\
\mathrm{CD}^{+} 7^{+}, \mathrm{CD} 34, \mathrm{CD} 45^{-}\end{array}$ & Favaron et al. (2014) \\
\hline
\end{tabular}

\& Orkin, 2006). Subsequently, hematopoietic cells are found in the aorta gonad mesonephros region (AGM), which appears after the development of the YS. The hematopoietic cells present in the AGM begin to colonize the fetal liver and later become permanently lodged in the bone marrow. The transition from the YS to the AGM is defined as primitive hematopoiesis, and after the lodging of hematopoietic cells in the bone marrow, it is defined as definitive hematopoiesis (Hyttel et al., 2009; McGrath \& Palis, 2005; Mikkola \& Orkin, 2006). These cells constitute the hematopoietic microenvironment existing in the marrow cavities of long and flat bones as well as in the spleen, liver, lymph nodes, and thymus (Robb et al., 1995; Shivdasani et al., 1995).

The term hematopoiesis can be defined as the ability to generate definitive mature cells through primitive cells (Hyttel et al., 2009; McGrath \& Palis, 2005; Mikkola \& Orkin, 2006). The hematopoietic system is an integrated network of cells that initiates the continuous cycle of differentiation of a small population of HSCs, which are pluripotent and produce all the heterogeneous functional cells of the blood and the immune system, thereby supporting a monophyletic theory of blood origin (Gasper, 2000). The HSCs are the only cells in the hematopoietic system that exhibit extensive proliferative potential and the ability to continuously differentiate into all cells of the lymphohematopoietic system until death (Gasper, 2000; Herzog et al., 2003).

HSCs are defined as cells with a high capacity for self-renewal and proliferative potential, which allow for differentiation into progenitor cells of all blood cells and the reconstitution of the hematopoietic population from a single cell. They comprise $0.05 \%$ to $0.1 \%$ of the human bone marrow and circulating hematopoietic cells (Grotto \& Noronha, 2003). HSCs can differentiate into all elements of the blood (red blood cells, leukocytes, and platelets) while maintaining the capacity for self-renewal that allows the maintenance of a sufficient number of stem cells for the production of these elements throughout an individual's life.

Owing to the plasticity of the hematopoietic system, many studies have been conducted on HSCs. Hematopoietic cells in the YS have previously been described in species, such as mice, goats, and bovines. Yamasaki et al. (2011) characterized the population of HSCs in the YS of rat embryos through the expression of CD45 and c-kit (CD117) markers. Gestational ages were measured based on the crown-rump length. High expression of CD117 and low expression of CD45 were noted at E9.5 to E14.5, and these cells could form colonies. 
The cell culture protocol used has been described briefly. The YS of embryos between E9.5 and E14.5 was excised from ICR mice and digested with $1 \mathrm{mg} / \mathrm{mL}$ dispase II for $20 \mathrm{~min}$ at $37^{\circ} \mathrm{C}$. The isolated cells were added to Hank's balanced salt solution containing $10 \%(\mathrm{v} / \mathrm{v})$ fetal calf serum and $250 \mu \mathrm{g} / \mathrm{mL}$ DNase I. The expression levels of the CD45 and c-kit markers were determined.

Pessolato et al. (2012) microscopically analyzed the YS of sheep and noticed that it comprised three layers, i.e., endoderm, mesoderm, and the mesothelium which included mesenchymal cells and various blood islands that are surrounded by endothelial cells. They identified and characterized hematopoietic cells from the sheep YS (gestational age 14 to 25 days). In culture, the HSCs exhibited non-adherent morphology and formed colonies in the methylcellulose matrix the day after they were plated. The expression of LMO2 at gestational day 25 was observed in the vitelline membrane.

Oliveira et al. (2017) characterized the hematopoietic cells of the YS. The bovine embryos were divided into different groups based on the gestational stages (25 to 50 days of gestational age). In culture, hematopoietic cells showed supernatants, exhibited the formation of cell clusters, and the more advanced gestational age groups could not be maintained in culture for an extended period. After cryopreservation, these cells exhibited the same morphology as that before freezing and could form colonies after 14 days when plated in a methylcellulose matrix. Flow cytometry revealed the expression of the hematopoietic markers CD34, CD90, and CD117, and decreased expression of CD117 and CD34 in the more advanced gestational age groups. qPCR revealed the presence of hematopoietic progenitor genes, GATA3 and LMO2 (Oliveira et al., 2017).

Cell culture of bovine and sheep YS follows the same protocol. The YS is washed with phosphatebuffered saline- $\mathrm{L}$-without calcium or magnesium-supplemented with antibiotics ( $5 \%$ penicillinstreptomycin) and macerated enzymatically with $0.5 \%$ collagenase IV for $1 \mathrm{~h}$. Subsequently, the enzymes are inactivated by the addition of the culture medium, Stem Pro ${ }^{\circledR}-34$ SFM (serum-free medium). The cells are plated in 24 -well plates and incubated at $37^{\circ} \mathrm{C}$ with $5 \% \mathrm{CO}_{2}$ and relative humidity at approximately $80 \%$.

\section{YS-derived mesenchymal stem cells}

Mesenchymal stem cells (MSCs) were initially described by Miao et al. (2006) as cells adhering to plastic in vitro that had the ability to differentiate into different cell lines of the mesodermal line upon stimulation (Dominici et al., 2006). In addition to the ability to differentiate, these cells are of great importance in regenerative medicine owing to their ability to mediate the immune response in injured tissues, e.g., immunomodulation for tissue regeneration (Miao et al., 2006). However, their characterization and clinical use remains challenging (Rossi \& Bonfim, 2020).

Initially, MSCs were derived from bone marrow; however, it is known that this cell population is small and decreases with age. Placental attachments, such as the chorion and the amniotic membrane serve as well-characterized alternative sources of MSCs (Ambrósio et al., 2020; Jones \& Jauniaux, 1995); however, few studies have investigated the culture of MSCs derived from the YS (Jang et al., 2013).

Isolation of MSCs from placental attachments is simpler because of the ease of obtaining these cells from extraembryonic structures, as this material is discarded during delivery (Filioli Uranio et al., 2011). In addition, the MSCs from placental attachments have an immunomodulatory capacity and can be transplanted (Weiss et al., 2008). MSCs derived from carnivore YS are highly plastic and are able to propagate in culture without any alterations in morphological and phenotypic characteristics or the loss of the ability to differentiate into multiple strains under specific conditions, thereby demonstrating a high potential for cell therapy (Motta, 2019; Wenceslau et al., 2011)

Two protocols have been developed to isolate canine YS-derived MSCs. Wenceslau et al. (2011) cultured fragments of YS in three different media in a controlled environment $\left(37^{\circ} \mathrm{C}\right.$ and $5 \%$ $\mathrm{CO}_{2}$ ) to observe which would be more appropriate for cell proliferation. The solution containing $\alpha$-minimum essential medium ( $\alpha$-MEM) supplemented with 15\% fetal bovine serum (FBS), $1 \%$ glutamine, antibiotic (ATB) solution, and non-essential amino acids (NEAA) was demonstrated to be more efficient than the other media. After characterization, these stem cells were found to have MSC-like morphology, with many organelles and irregular membranes with expansive growth; they were also able to differentiate into chondrocytes and osteocytes and form colonies. 
Giacomini et al. (2017) and Motta (2019) used collagenase IV to isolate the MSCs from the tissue by cultivating the cells for $1 \mathrm{~h}$ in $\alpha$-MEM supplemented with $15 \% \mathrm{FBS}, 1 \%$ glutamine, ATB solution, and NEAA. These cells displayed an expansion in growth after the fourth day of culture, showing peak growth at the fifth passage, and were positive for the membrane marker, $\mathrm{CD} 105$, and negative for CD34 and CD45, which are characteristic markers of MSCs. In addition, these cells could develop colonies and differentiate into three cell lines, besides being 70\% viable after freezing (Motta, 2019). To date, no study has been conducted on the isolation of feline YS-derived MSCs.

Franciolli et al. (2020) demonstrated that is possible to isolate cells from the YS tissues of equine animals for up to day 40 of gestation. The process of isolation consists of mechanically macerating the YS tissue and culturing in presence of $1 \mathrm{mLFBS}$ for $24 \mathrm{~h}$ at $37^{\circ} \mathrm{C}$ in an atmosphere of $5 \% \mathrm{CO}_{2}$. Thereafter, $5 \mathrm{~mL}$ of $\alpha$-MEM supplemented with $20 \% \mathrm{FBS}, 1 \%$ NEAA, $1 \%$ L-glutamine, and $1 \%$ ATB was added. The cells were cultured until passage 10 and had MSC-like morphology, could form colony-forming units, adhered to plastic, and could be differentiated into adipocytes, osteocytes, and chondrocytes. In addition, the cells expressed CD45, CD34, CD105, OCT3/4, Nanog, and Stro-1. The immunophenotypic diversity is explained by the isolation method selected by the authors, where selection between hematopoietic and mesenchymal cells was not performed.

Bertassoli et al. (2015) isolated and characterized MSCs derived from the swine YS. The cells were collected from YS tissue at day 30 of gestation. The tissue was macerated and enzymatically processed with trypsin $2.5 \%$ for $5 \mathrm{~min}$. After isolation, the cells were cultured in Dulbecco's modified Eagle medium, supplemented with 15\% FBS, 2\% NEAA, 3\% L-glutamine, 280 mM HEPES, 0.5\% sodium bicarbonate (NaHCO3), and $1 \%$ ATB. The cells were incubated at $37^{\circ} \mathrm{C}$ in an atmosphere containing 5\% $\mathrm{CO}_{2}$ and cultured until passage 6 . The cells exhibited MSC-like morphology and were positive for the CD90, CD105, CD117, vimentin, Stro-1, Oct-4, vascular endothelial growth factor, beta-tubulin, cytokeratin, Nanog, and PCNA and were negative for CD45 (Bertassoli et al., 2015; Kolf et al., 2007). In addition, the potential for chondrogenic, adipogenic, and osteogenic differentiation has been successfully demonstrated in stem cells obtained from swine YS (Seifert, 2014).

Mançanares et al. (2015) developed the protocol to isolate, culture, and characterize MSCs from bovine YS. The YS was collected between days 20 and 50 of gestation. The tissue was isolated using a mechanical and enzymatic process (collagenase type IV for $5 \mathrm{~min}$ ). After isolation, the cells were cultured in $\alpha$-MEM, supplemented with 10\% FBS, 1\% NEAA, 1\% BME amino acid solution, $1 \% \beta$-mercaptoethanol, and $1 \%$ ATB and incubated at $37^{\circ} \mathrm{C}$ in an atmosphere containing $5 \% \mathrm{CO}_{2}$. The cells were cultured until passage 11 . From the sixth day of culture, the cells could form colony-forming units and presented MSC-like morphology.

Stem cells derived from bovine YS were positive for CD90 and CD105 and negative for CD79, CD44, and CD45, characteristic of MSCs (Kolf et al., 2007; Mançanares et al., 2015) and could be differentiated into osteocytes, chondrocytes, and adipocytes. In addition, the isolated stem cells could not form teratomas when transplanted into nude immunodeficient mice (BALB/c-Nu), making these cells suitable for use in regenerative therapies without the risk of teratoma formation. Furthermore, the YS MSCs of bovine embryos exhibited spontaneous formation of tubular structures in vitro similar to blood vessel-like structures without growth factors; expression of vascular endothelial growth factor revealed that the YS may play an important role in vascular development (Mançanares et al., 2019).

In humans, because the YS regresses during pregnancy, studies commonly evaluate the presence of MSCs in fetal attachments collected from other membranes, such as the amnion and chorion (Miao et al., 2006; Soncini et al., 2007). It is well established that cells cultured from the human placenta show differentiation capacity in osteogenic, chondrogenic, adipogenic, myogenic (Soncini et al., 2007), and neurogenic (Pop et al., 2015) strains. Miao et al. (2006) performed immunophenotypic characterization using flow cytometry, and found that cells derived from the amnion and chorion were CD44+, CD105+, CD29+, CD19-, CD106-, CD45-, CD34-, and HLADR-. Kadam et al. (2010) characterized the cells derived from the human chorion and found that they were CD44+, CD105+, CD117+, CD10-, CD34-, CD45, and CD166-, and revealed the ability of these cells to differentiate into cells similar to pancreatic islets.

Wang et al. (2008) collected YS from human fetuses (between 25 and 40 days from volunteers who had opted to terminate the pregnancy). Each sample was dissected in a culture plate containing 
cold phosphate-buffered saline (PBS) under a microscope. For enzymatic dissociation of the tissue, collagenase type I (0.1\%) was used in PSB with $20 \% \mathrm{FBS}$ for $1 \mathrm{~h}$ at $37^{\circ} \mathrm{C}$. The dissociated cells were plated at a concentration of $5 \times 10^{3} \mathrm{cells} / \mathrm{cm}^{2}$ in $\alpha$-MEM supplemented with $10 \% \mathrm{FBS}$, $1 \% \mathrm{ATB}$, and $5 \mathrm{ng} / \mathrm{mL}$ bFGF. The cells were incubated at $37^{\circ} \mathrm{C}$ in an atmosphere containing $5 \%$ $\mathrm{CO}_{2}$, and after $48 \mathrm{~h}$, the non-adherent cells were removed. When the cells reached a confluency of 70-80\%, they were detached from culture plates using trypsin/0.25\% EDTA. The cells presented MSC-like morphology, as well as the ability to adhere to plastic and expand in the culture plate. With respect to differentiation into mesoderm strains, differentiation was observed only for the adipogenic and osteogenic lineages, and not for in vitro chondrogenic strains.

In addition to research on domestic animals and humans, research on MSCs in new animal models, including unconventional species, such as wild animals, can generate promising results with respect to cell dynamics in vitro and in vivo, which represents an important advancement in cell culture and use.

Favaron et al. (2014) studied the culturing of stem cells derived from the YS of the New World mouse (Necromys lasiurus), a rodent from Latin America. The YS was collected from 15-16-day old fetuses and placed in culture plates after cell isolation, at $37^{\circ} \mathrm{C}$ in an atmosphere of $5 \% \mathrm{CO}_{2}$. The cells were cultured in Dulbecco's modified Eagle medium-high glucose supplemented with 10\% FBS, 1\% antibiotic, 1\% L-glutamine and 1\% NEAA. The culture medium was changed every 3 days and the cells were maintained until 70\% confluence. The cultured cells remained in fibroblastic morphology and showed growth until P4, entering senescence and reaching P6. In addition, flow cytometry revealed that cells derived from the YS of the New World mouse were positive for CD90, CD105, CD73, and CD117 and did not express CD34 and CD45. Moreover, cultured cells could differentiate into adipogenic, chondrogenic, and osteogenic strains.

\section{YS in regenerative medicine and cellular therapy}

The ability of MSCs to differentiate into different cell lineages and to secrete diverse bioactive molecules responsible for mediating the immune response, i.e., immunomodulation has fueled interest in MSCs (Abumaree et al., 2017).

MSCs can stimulate cells of the immune system, both by direct cell-cell contact and through modulation of inflammation. These cells induce the release of extracellular vesicles with paracrine capacity and secrete growth factors, cytokines, and other bioactive molecules, all of which result in immune modulation (Crivelli et al., 2017; Özen et al., 2012; Trohatou \& Roubelakis, 2017). It is known that MSCs can regulate the expression of anti-inflammatory molecules and growth factors related to angiogenesis and reduction of apoptosis; they can negatively regulate pro-inflammatory cytokines (Uranio et al., 2011).

The secreted factors and their quality depend on the physiology of the donor; however, these factors are mainly observed in fetal tissue-derived cells. To our knowledge, no study has assessed the immunomodulation capacity of MSCs derived from the YS; however, it is known that MSCs can inhibit the proliferation of Tlymphocytes, as well as downregulate the expression of cytokines IL-2, IL-12, TNF- $\alpha$, and IFN- $\gamma$ and increase the release of IL-1O, IL-4, IL-6, and IL-17 from stem cells derived from the human placenta (Abumaree et al., 2017). MSCs derived from adipose tissue and bone marrow have also been demonstrated to perform immunomodulation similar to cells derived from the placenta; however, cells in fetal membranes exhibit higher levels of cytokines IL-2, IL-4, and IL-13 (Lee et al., 2012).

In addition, MSCs derived from the canine YS were recently used in cell therapy in dogs with hip dysplasia, where they ameliorated the symptoms (Moyle et al., 2019). This model exhibits remarkable similarities with humans compared to other traditional models, being predominantly used for research in cell transplantation because it exhibits stem cell kinetics similar to those observed in humans (Bentin-Ley et al., 1994).

\section{Conclusion and future directions}

Although few therapeutic studies have been conducted to date with stem cells derived from placental attachments, MSCs from dogs and cats are commonly used as models for the treatment of several pathologies, such as osteoarthritis (Guercio et al., 2012), spinal cord injury (Kim et al., 
2015; Penha et al., 2012), autoimmune diseases (Tyndall \& Uccelli, 2009), renal dysfunction (Quimby et al., 2016; Vidane et al., 2017), Duchenne muscular dystrophy (Hyzewicz et al., 2017), and heart disease (Kim et al., 2010). Thus, stem cells derived from the YS can serve as an important source for cell therapy in different species.

\section{Ethics statement}

Not applicable (review article).

\section{Financial support}

PAFP - Received scholarship - grant \#2018/11752-7 the São Paulo Research Foundation (FAPESP). VMP, VCO - Received scholarship from São Paulo Research Foundation (FAPESP). CEA - Coordenação de Aperfeiçoamento de Pessoal de Nível Superior - Brasil (CAPES) - Finance Code 001; and grant \#2017/21266-0 the São Paulo Research Foundation (FAPESP). LCBM, MFA, TGS, LCM - None.

\section{Conflict of interests}

No conflict of interest.

\section{Authors' contributions}

PAFP, VMP, LCBM, MFA, TGS, VCO, LCM - Writing, Review and Editing manuscript. CEA Acquisition of the financial support for the project leading to this publication, Review manuscript.

\section{Availability of complementary results}

The work was carried out at Laboratório de cultivo de células tronco e terapia gênica, Faculty of Animal Science and Food Engineering, University of São Paulo, Pirassununga, São Paulo, Brazil.

\section{References}

Abumaree, M. H., Abomaray, F. M., Alshabibi, M. A., AlAskar, A. S., \& Kalionis, B. (2017). Immunomodulatory properties of human placental mesenchymal stem/stromal cells. Placenta, 59, 87-95. http://dx.doi.org/10.1016/j. placenta.2017.04.003. PMid:28411943.

Ambrósio, C. E., Orlandin, J. R., Oliveira, V. C., Motta, L., Pinto, P., Pereira, V. M., Padoveze, L. R., Karam, R. G., \& Pinheiro, A. O. (2020). Potential application of aminiotic stem cells in veterinary medicine. Animal Reproduction, 16(1), 24-30. http://dx.doi.org/10.21451/1984-3143-AR2018-0124. PMid:33299475.

Bentin-Ley, U., Pedersen, B., Lindenberg, S., Larsen, J. F., Hamberger, L., \& Horn, T. (1994). Isolation and culture of human endometrial cells in a three-dimensional culture system. Journal of Reproduction and Fertility, 101(2), 327-332. http://dx.doi.org/10.1530/jrf.0.1010327. PMid:7932366.

Bertassoli, B. M., Santos, A. C., Fratini, P., Will, S. E. A. L., Rodrigues, M. N., Chaves, A., \& Assis Neto , A. C. (2015). Isolamento e caracterização de células-tronco do saco vitelino de suínos domésticos (Sus scrofa). Archives of Veterinary Science, 20(3), 1-10.

Bian, Z., Gong, Y., Huang, T., Lee, C., Bian, L., Bai, Z., Shi, H., Zeng, Y., Liu, C., He, J., Zhou, J., Li, X., Li, Z., Ni, Y., Ma, C., Cui, L., Zhang, R., Chan, J., Ng, L. G., Lan, Y., Ginhoux, F., \& Liu, B. (2020). Deciphering human macrophage development at single-cell resolution. Nature, 582(7813), 571-576. http://dx.doi.org/10.1038/s41586-020-23167. PMid:32499656.

Bobis, S., Jarocha, D., \& Majka, M. (2006). Mesenchymal stem cells: characteristics and clinical applications. Folia Histochemica et Cytobiologica, 44(4), 215-230. PMid:17219716.

Borghesi, J., Ferreira Lima, M., Mario, L. C., de Almeida da Anunciação, A. R., Silveira Rabelo, A. C., Giancoli Kato Cano da Silva, M., Assunpção Fernandes, F., Miglino, M. A., Oliveira Carreira, A. C., \& Oliveira Favaron, P. (2019). Canine amniotic membrane mesenchymal stromal/stem cells: isolation, characterization and differentiation. Tissue \& Cell, 58, 99-106. http://dx.doi.org/10.1016/j.tice.2019.04.007. PMid:31133253.

Brent, R. L., \& Fawcett, L. B. (1998). Nutritional studies of the embryo during early organogenesis with normal embryos and embryos exhibiting yolk sac dysfunction. The Journal of Pediatrics, 132(3 Pt 2), S6-S16. http:// dx.doi.org/10.1016/S0022-3476(98)70522-0. PMid:9546031.

Burton, G. J., Watson, A. L., Hempstock, J., Skepper, J. N., \& Jauniaux, E. (2002). Uterine glands provide histiotrophic nutrition for the human fetus during the first trimester of pregnancy. The Journal of Clinical Endocrinology and Metabolism, 87(6), 2954-2959. http://dx.doi.org/10.1210/jcem.87.6.8563. PMid:12050279. 
Carter, A. M., \& Enders, A. C. (2016). Placentation in mammals: definitive placenta, yolk sac, and paraplacenta. Theriogenology, 86(1), 278-287. http://dx.doi.org/10.1016/j.theriogenology.2016.04.041. PMid:27155730.

Choi, K., Kennedy, M., Kazarov, A., Papadimitriou, J. C., \& Keller, G. (1998). A common precursor for hematopoietic and endothelial cells. Development, 125(4), 725-732. http://dx.doi.org/10.1242/dev.125.4.725. PMid:9435292.

Cremonesi, F., Corradetti, B., \& Lange Consiglio, A. (2011). Fetal adnexa derived stem cells from domestic animal: progress and perspectives. Theriogenology, 75(8), 1400-1415. http://dx.doi.org/10.1016/j.theriogenology.2010.12.032. PMid:21463720.

Crivelli, B., Chlapanidas, T., Perteghella, S., Lucarelli, E., Pascucci, L., Brini, A. T., Ferrero, I., Marazzi, M., Pessina, A., \& Torre, M. L. (2017). Mesenchymal stem/stromal cell extracellular vesicles: From active principle to next generation drug delivery system. Journal of Controlled Release, 262, 104-117. http://dx.doi.org/10.1016/i. jconrel.2017.07.023.

Cumano, A., Furlonger, C., \& Paige, C. J. (1993). Differentiation and characterization of B-cell precursors detected in the yolk sac and embryo body of embryos beginning at the 10- to 12-somite stage. Proceedings of the National Academy of Sciences of the United States of America, 90(14), 6429-6433. http://dx.doi.org/10.1073/ pnas.90.14.6429. PMid:8341650.

Dominici, M., Le Blanc, K., Mueller, I., Slaper-Cortenbach, I., Marini, F., Krause, D., Deans, R., Keating, A., Prockop, D., \& Horwitz, E. (2006). Minimal criteria for defining multipotent mesenchymal stromal cells. Cytotherapy, 8(4), 315-317. http://dx.doi.org/10.1080/14653240600855905. PMid:16923606.

Dong, D., Reece, E. A., Lin, X., Wu, Y., AriasVillela, N., \& Yang, P. (2016). New development of the yolk sac theory in diabetic embryopathy: Molecular mechanism and link to structural birth defects. American Journal of Obstetrics and Gynecology, 214(2), 192-202. http://dx.doi.org/10.1016/j.ajog.2015.09.082. PMid:26432466.

Dzierzak, E., \& Robin, C. (2010). Placenta as a source of hematopoietic stem cells. Trends in Molecular Medicine, 16(8), 361-367. http://dx.doi.org/10.1016/j.molmed.2010.05.005. PMid:20580607.

Favaron, P. O., Mess, A., Will, S. E., Maiorka, P. C., Oliveira, M. F., \& Miglino, M. A. (2014). Yolk sac mesenchymal progenitor cells from New World mice (Necromys lasiurus) with multipotent differential potential. PLoS One, 9(2), e95575. http://dx.doi.org/10.1371/journal.pone.0095575. PMid:24918429.

Filioli Uranio, M., Valentini, L., Lange-Consiglio, A., Caira, M., Guaricci, A. C., L'Abbate, A., Catacchio, C. R., Ventura, M., Cremonesi, F., \& Dell'Aquila, M. E. (2011). Isolation, proliferation, cytogenetic, and molecular characterization and in vitro differentiation potency of canine stem cells from foetal adnexa: a comparative study of amniotic fluid, amnion, and umbilical cord matrix. Molecular Reproduction and Development, 78(5), 361-373. http:// dx.doi.org/10.1002/mrd.21311. PMid:21491540.

Franciolli, A. L. R., Barreto, R. S. N., Matias, G., Carvalho, R. C., Rodrigues, M. N., Fratini, P., Pignatari, G. C., Rechsteiner, S. M. E. F., Mess, A. M., \& Miglino, M. A. (2020). Equine yolk sac: a stem cells source. International Journal of Morphology, 38(5), 1412-1420. http://dx.doi.org/10.4067/S0717-95022020000501412.

Fratini, P., Carreira, A. C., Alcântara, D., de Oliveira e Silva, F. M., Rodrigues, M. N., \& Miglino, M. A. (2016). Endothelial differentiation of canine yolk sac cells transduced with VEGF. Research in Veterinary Science, 104, 71-76. http:// dx.doi.org/10.1016/j.rvsc.2015.11.010. PMid:26850540.

Freyer, C., \& Renfree, M. B. (2009). The mammalian yolk sac placenta. Journal of Experimental Zoology. Part B, Molecular and Developmental Evolution, 312(6), 545-554. http://dx.doi.org/10.1002/jez.b.21239. PMid:18985616.

Galdos-Riveros, A., Rezende, L. C., Pessolato, A., Zogno, M. A., Rici, R. E. M., \& Miglino, A., (2012). The structure of the bovine yolk sac: a study microscopic. In A. Méndez-Vilas (Ed.), Current microscopy contributions to advances in science and technology. Badajoz: Formatex.

Gasper, P. W. (2000). The hemopoietic system. In B. F. Feldman(Ed.), Schalm's veterinary hematology (pp. 63-68). London: Lippincott Williams \& Wilkins.

Giacomini, E., Vago, R., Sanchez, A. M., Podini, P., Zarovni, N., Murdica, V., Rizzo, R., Bortolotti, D., Candiani, M., \& Viganò, P. (2017). Secretome of in vitro cultured human embryos contains extracellular vesicles that are uptaken by the maternal side. Scientific Reports, 7(1), 1-13. http://dx.doi.org/10.1038/s41598-017-05549-w. PMid:28701751.

Grotto, H. Z. W., \& Noronha, J. F. A. (2003). Identificação de células tronco hematopoiéticas: Citometria de fluxo convencional versus contador hematológico automatizado. Revista Brasileira de Hematologia e Hemoterapia, 25(3), 169-172. http://dx.doi.org/10.1590/S1516-84842003000300008.

Guercio, A., Di Marco, P., Casella, S., Cannella, V., Russotto, L., Purpari, G., Di Bella, S., \& Piccione, G. (2012). Production of canine mesenchymal stem cells from adipose tissue and their application in dogs with chronic osteoarthritis of the humeroradial joints. Cell Biology International, 36(2), 189-194. http://dx.doi.org/10.1042/ CBI20110304. PMid:21936851

Gulbis, B., Jauniaux, E., Cotton, F., \& Stordeur, P. (1998). Protein and enzyme patterns in the fluid cavities of the first trimester gestational sac: Relevance to the absorptive role of secondary yolk sac. Molecular Human Reproduction, 4(9), 857-862. http://dx.doi.org/10.1093/molehr/4.9.857. PMid:9783845.

Hafez, S. (2017). Comparative placental anatomy: Divergent structures serving a common purpose. Progress in Molecular Biology and Translational Science, 145, 1-28. http://dx.doi.org/10.1016/bs.pmbts.2016.12.001. PMid:28110748. 
Herzog, E. L., Chai, L., \& Krause, D. S. (2003). Plasticity of marrow-derived stem cells. Blood, 102(10), 3483-3493. http://dx.doi.org/10.1182/blood-2003-05-1664. PMid:12893756.

Huang, H., \& Auerbach, R. (1993). Identification and characterization of hematopoietic stem cells from the yolk sac of the early mouse embryo. Proceedings of the National Academy of Sciences of the United States of America, 90(21), 10110-10114. http://dx.doi.org/10.1073/pnas.90.21.10110. PMid:8234265.

Hyttel, P., Sinowatz, F., Vejlsted, M., \& Betteridge, K. (2009). Essentials of domestic animal embryology. Edinburgh: Elsevier Health Sciences.

Hyzewicz, J., Tanihata, J., Kuraoka, M., Nitahara-Kasahara, Y., Beylier, T., Ruegg, U. T., Vater, A., \& Takeda, S. (2017). Low-Intensity Training and the C5a Complement Antagonist NOX-D21 Rescue the mdx Phenotype through Modulation of Inflammation. American Journal of Pathology, 187(5), 1147-1161. http://dx.doi.org/10.1016/j. ajpath.2016.12.019. PMid:28315675.

Jang, M. J., Kim, H.-S., Lee, H.-G., Kim, G. J., Jeon, H. G., Shin, H.-S., Chang, S.-K., Hur, G.-H., Chong, S. Y., Oh, D., \& Chung, H.-M. (2013). Placenta-derived mesenchymal stem cells have an immunomodulatory effect that can control acute graft-versus-host disease in mice. Acta Haematologica, 129(4), 197-206. http://dx.doi. org/10.1159/000345267. PMid:23257958.

Jones, C. J., \& Jauniaux, E. (1995). Ultrastructure of the materno-embryonic interface in the first trimester of pregnancy. Micron, 26(2), 145-173. http://dx.doi.org/10.1016/0968-4328(95)00002-L. PMid:7767634.

Kadam, S., Muthyala, S., Nair, P., \& Bhonde, R. (2010). Human placenta-derived mesenchymal stem cells and islet-like cell clusters generated from these cells as a novel source for stem cell therapy in diabetes. The Review of Diabetic Studies, 7(2), 168-182. http://dx.doi.org/10.1900/RDS.2010.7.168. PMid:21060975.

Kim, S. K., Pak, H. N., Park, J. H., Fang, Y. F., Kim, G. I., Park, Y. D., Hwang, C., Kim, Y. H., \& Kim, B. S. (2O10). Cardiac cell therapy with mesenchymal stem cell induces cardiac nerve sprouting, angiogenesis, and reduced connexin43-positive gap junctions, but concomitant electrical pacing increases connexin43-positive gap junctions in canine heart. Cardiology in the Young, 20(3), 308-317. http://dx.doi.org/10.1017/S1047951110000132. PMid:20346202.

Kim, Y., Jo, S. H., Kim, W. H., \& Kweon, O. K. (2015). Antioxidant and anti-inflammatory effects of intravenously injected adipose derived mesenchymal stem cells in dogs with acute spinal cord injury. Stem Cell Research \& Therapy, 6(1), 229. http://dx.doi.org/10.1186/s13287-015-0236-5. PMid:26612085.

King, B. F., \& Enders, A. C. (1970). Protein absorption and transport by the guinea pig visceral yolk sac placenta. The American Journal of Anatomy, 129(3), 261-287. http://dx.doi.org/10.1002/aja.1001290303. PMid:5476175.

Kolf, C. M., Cho, E., \& Tuan, R. S. (2007). Mesenchymal stromal cells. Biology of adult mesenchymal stem cells: Regulation of niche, self-renewal and differentiation. Arthritis Research \& Therapy, 9(1), 204. http://dx.doi. org/10.1186/ar2116. PMid:17316462.

Lee, J. M., Jung, J., Lee, H. J., Jeong, S. J., Cho, K. J., Hwang, S. G., \& Kim, G. J. (2012). Comparison of immunomodulatory effects of placenta mesenchymal stem cells with bone marrow and adipose mesenchymal stem cells. International Immunopharmacology, 13(2), 219-224. http://dx.doi.org/10.1016/j.intimp.2012.03.024. PMid:22487126.

Lin, L., Yee, S. W., Kim, R. B., \& Giacomini, K. M. (2015). SLC transporters as therapeutic targets: Emerging opportunities. Nature Reviews. Drug Discovery, 14(8), 543-560. http://dx.doi.org/10.1038/nrd4626. PMid:26111766.

Mançanares, C. A. F., Oliveira, V. C., Oliveira, L. J., Carvalho, A. F., Sampaio, R. V., Mançanares, A. C. F., Souza, A. F., Perecin, F., Meirelles, F. V., Miglino, M. A., \& Ambrósio, C. E. (2015). Isolation and characterization of mesenchymal stem cells from the yolk sacs of bovine embryos. Theriogenology, 84(6), 887-898. http://dx.doi. org/10.1016/j.theriogenology.2015.05.031. PMid:26143361.

Mançanares, A., Oliveira, V. C., Oliveira, L. J., Miglino, M. A., Meirelles, F. V., \& Ambrósio, C. E. (2019). Morphological and molecular analysis of in vitro tubular structures from bovine yolk sac-derived MSCs. Stem Cells International, 2019, 5073745. http://dx.doi.org/10.1155/2019/5073745.

McGrath, K. E., \& Palis, J. (2005). Hematopoiesis in the yolk sac: More than meets the eye. Experimental Hematology, 33(9), 1021-1028. http://dx.doi.org/10.1016/j.exphem.2005.06.012. PMid:16140150.

Mess, A. M., Carreira, A. C. O., Marinovic de Oliveira, C., Fratini, P., Favaron, P. O., Barreto, R., Pfarrer, C., Meirelles, F. V., \& Miglino, M. A. (2017). Vascularization and VEGF expression altered in bovine yolk sacs from IVF and NT technologies. Theriogenology, 87,290-297. http://dx.doi.org/10.1016/j.theriogenology.2016.09.012. PMid:27729111.

Miao, Z., Jin, J., Chen, L., Zhu, J., Huang, W., Zhao, J., Qian, H., \& Zhang, X. (2006). Isolation of mesenchymal stem cells from human placenta: Comparison with human bone marrow mesenchymal stem cells. Cell Biology International, 30(9), 681-687. http://dx.doi.org/10.1016/j.cellbi.2006.03.009. PMid:16870478.

Miglino, M. A., Ambrósio, C. E., Martins, D. DOS S., Wenceslau, C. V., Pfarrer, C., \& Leiser, R. (2006). The carnivore pregnancy: The development of the embryo and fetal membranes. Theriogenology, 66(6-7), 1699-1702. http:// dx.doi.org/10.1016/j.theriogenology.2006.02.027. PMid:16563485.

Mikkola, H. K., \& Orkin, S. H. (2006). The journey of developing hematopoietic stem cells. Development, 133(19), 3733-3744. http://dx.doi.org/10.1242/dev.02568. PMid:16968814.

Motta, L. C. B. (2019). Geração de organóides intestinais a partir de células-tronco derivadas do saco vitelino canino [Dissertação de mestrado]. Universidade de São Paulo. https://doi.org/10.11606/D.10.2020.tde-02122019-163753.

Moyle, L. A., Tedesco, F. S., \& Benedetti, S. (2019). Pericytes in muscular dystrophies. Advances in Experimental Medicine and Biology, 1147, 319-344. http://dx.doi.org/10.1007/978-3-030-16908-4_15. PMid:31147885. 
Myren, M., Mose, T., Mathiesen, L., \& Knudsen, L. E. (2007). The human placenta: An alternative for studying foetal exposure. Toxicology In Vitro, 21(7), 1332-1340. http://dx.doi.org/10.1016/j.tiv.2007.05.011. PMid:17624715.

Oliveira, V. C., Mançanares, C. A., Oliveira, L. J., Gonçalves, N. J., Miglino, M. A., Perecin, F., Meirelles, F. V., Piedrahita, J., \& Ambrósio, C. E. (2017). Characterization of putative haematopoietic cells from bovine yolk sac. Journal of Tissue Engineering and Regenerative Medicine,11(4),1132-1140. http://dx.doi.org/10.1002/term.2016. PMid:25712733.

Özen, I., Boix, J., \& Paul, G. (2012). Perivascular mesenchymal stem cells in the adult human brain: A future target for neuroregeneration? Clinical and Translational Medicine, 1(1), 30. http://dx.doi.org/10.1186/2001-1326-1-30. PMid:23369339.

Palis, J., \& Yoder, M. C. (2001). Yolk-sac hematopoiesis: The first blood cells of mouse and man. Experimental Hematology, 29(8), 927-936. http://dx.doi.org/10.1016/S0301-472X(01)00669-5. PMid:11495698.

Penha, E. M., Aguiar, P. H. P., Barrouin-Melo, S. M., Lima, R. S., Silveira, A. C. C., Otelo, A. R. S., Pinheiro, C. M. B., Ribeiro-dos-Santos, R., \& Soares, M. B. P. (2012). Clinical neurofunctional rehabilitation of a cat with spinal cord injury after hemilaminectomy and autologous stem cell transplantation. International Journal of Stem Cells, 5(2), 146-150. http://dx.doi.org/10.15283/ijsc.2012.5.2.146. PMid:24298368.

Pessolato, A. G. T., Martins, D. S., Galdos-Riveros, A., Fontes, A. M., Ambrósio, C. E., Grassi, R. E., \& Miglino, M. A. (2012). Microscopic aspects of the yolk sac hematopoiesis from ovine embryos. In A. Méndez-Vilas (Ed.), Current microscopy contributions to advances in science and technology. Badajoz: Formatex.

Pop, D. M., Sorițău, O., Şuşman, S., Rus-Ciucă, D., Groza, I. Ş., Ciortea, R., Mihu, D., \& Mihu, C. M. (2015). Potential of placental-derived human mesenchymal stem cells for osteogenesis and neurogenesis. Romanian Journal of Morphology and Embryology, 56(3), 989-996. PMid:26662130.

Quimby, J. M., Webb, T. L., Randall, E., Marolf, A., Valdes-Martinez, A., \& Dow, S. W. (2016). Assessment of intravenous adipose-derived allogeneic mesenchymal stem cells for the treatment of feline chronic kidney disease: A randomized, placebo-controlled clinical trial in eight cats. Journal of Feline Medicine and Surgery, 18(2), 165-171. http://dx.doi.org/10.1177/1098612X15576980. PMid:25784460.

Raeside, J. I., Christie, H. L., Renaud, R. L., Waelchli, R. O., \& Betteridge, K. J. (2004). Estrogen metabolism in the equine conceptus and endometrium during early pregnancy in relation to estrogen concentrations in yolk-sac fluid. Biology of Reproduction, 71(4), 1120-1127. http://dx.doi.org/10.1095/biolreprod.104.028712. PMid:15163615.

Robb, L., Lyons, I., Li, R., Hartley, L., Köntgen, F., Harvey, R. P., Metcalf, D., \& Begley, C. G. (1995). Absence of yolk sac hematopoiesis from mice with a targeted disruption of the scl gene. Proceedings of the National Academy of Sciences of the United States of America, 92(15), 7075-7079. http://dx.doi.org/10.1073/pnas.92.15.7075. PMid:7624372.

Rossi, M. I. D., \& Bonfim, D. C. (2020). Mesenchymal stromal/stem cells: historical perspective and ongoing challenges. Revista Brasileira de Medicina Veterinária, 52(1), 1-16. http://dx.doi.org/10.29374/2527-2179.bjvm112020.

Saulnier, N., Loriau, J., Febre, M., Robert, C., Rakic, R., Bonte, T., Buff, S., \& Maddens, S. (2016). Canine placenta: A promising potential source of highly proliferative and immunomodulatory mesenchymal stromal cells? Veterinary Immunology and Immunopathology, 171, 47-55. http://dx.doi.org/10.1016/j.vetimm.2016.02.005. PMid:26964717.

Seifert, J. (2014). Changes in mouse liver and chicken embryo yolk sac membrane soluble proteins due to an organophosphorous insecticide (OPI) diazinon linked to several noncholinergic OPI effects in mice and chicken embryos. Pesticide Biochemistry and Physiology,116,74-82.http://dx.doi.org/10.1016/j.pestbp.2014.09.016. PMid:25454523.

Shivdasani, R. A., Mayer, E. L., \& Orkin, S. H. (1995). Absence of blood formation in mice lacking the T-cell leukaemia oncoprotein tal-1/SCL. Nature, 373(6513), 432-434. http://dx.doi.org/10.1038/373432aO. PMid:7830794.

Soncini, M., Vertua, E., Gibelli, L., Zorzi, F., Denegri, M., Albertini, A., Wengler, G. S., \& Parolini, O. (2007). Isolation and characterization of mesenchymal cells from human fetal membranes. Journal of Tissue Engineering and Regenerative Medicine, 1(4), 296-305. http://dx.doi.org/10.1002/term.40. PMid:18038420.

Sousa, C., Biber, K., \& Michelucci, A. (2017). Cellular and Molecular Characterization of Microglia: A Unique Immune Cell Population. Frontiers in Immunology, 8, 198. http://dx.doi.org/10.3389/fimmu.2017.00198. PMid:28303137.

Stremmel, C., Schuchert, R., Wagner, F., Thaler, R., Weinberger, T., Pick, R., Mass, E., Ishikawa-Ankerhold, H. C., Margraf, A., Hutter, S., Vagnozzi, R., Klapproth, S., Frampton, J., Yona, S., Scheiermann, C., Molkentin, J. D., Jeschke, U., Moser, M., Sperandio, M., Massberg, S., Geissmann, F., \& Schulz, C. (2018). Yolk sac macrophage progenitors traffic to the embryo during defined stages of development. Nature Communications, 9(1), 1-14. http://dx.doi.org/10.1038/s41467-017-02492-2. PMid:29317637.

Thomas, T., Southwell, B. R., Schreiber, G., \& Jaworowski, A. (1990). Plasma protein synthesis and secretion in the visceral yolk sac of the fetal rat: Gene expression, protein synthesis and secretion. Placenta, 11(5), 413-430. http://dx.doi.org/10.1016/S0143-4004(05)80216-4. PMid:1707170.

Tiedemann, K., \& Minuth, W. W. (1980). The pig yolk sac I - Fine structure of the posthaematopoietic organ. Histochemistry, 68(2), 133-146. http://dx.doi.org/10.1007/BF00489509. PMid:7419438.

Trohatou, O., \& Roubelakis, M. G. (2017). Mesenchymal stem/stromal cells in regenerative medicine: past, present, and future. Cellular Reprogramming, 19(4), 217-224. http://dx.doi.org/10.1089/cell.2016.0062. PMid:28520465.

Tyndall, A., \& Uccelli, A. (2009). Multipotent mesenchymal stromal cells for autoimmune diseases: Teaching new dogs old tricks. Bone Marrow Transplantation, 43(11), 821-828. http://dx.doi.org/10.1038/bmt.2009.63. PMid:19308035. 
Umezawa, A., Hasegawa, A., Inoue, M., Tanuma-Takahashi, A., Kajiwara, K., Makino, H., Chikazawa, E., \& Okamoto, A. (2019). Amnion-derived cells as a reliable resource for next-generation regenerative medicine. Placenta, 84, 50-56. http://dx.doi.org/10.1016/j.placenta.2019.06.381. PMid:31272680.

Uranio, M. F., Valentini, L., Lange-Consiglio, A., Caira, M., Guaricci, A. C., L'Abbate, A., Catacchio, C. R., Ventura, M., Cremonesi, F., \& Dell'Aquila, M. E. (2011). Isolation, proliferation, cytogenetic, and molecular characterization and in vitro differentiation potency of canine stem cells from foetal adnexa: A comparative study of amniotic fluid, amnion, and umbilical cord matrix. Molecular Reproduction and Development, 78(5), 361-373. http:// dx.doi.org/10.1002/mrd.21311. PMid:21491540.

Vanover, M., Wang, A., \& Farmer, D. (2017). Potential clinical applications of placental stem cells for use in fetal therapy of birth defects. Placenta, 59,107-112. http://dx.doi.org/10.1016/j.placenta.2017.05.010. PMid:28651900.

Vidane, A. S., Pinheiro, A. O., Casals, J. B., Passarelli, D., Hage, M. C. F. N. S., Bueno, R. S., Martins, D. S., \& Ambrósio, C. E. (2017). Transplantation of amniotic membrane-derived multipotent cells ameliorates and delays the progression of chronic kidney disease in cats. Reproduction in Domestic Animals, 52(Suppl 2), 316-326. http:// dx.doi.org/10.1111/rda.12846. PMid:27774657.

Wang, X. Y., Lan, Y., He, W. Y., Zhang, L., Yao, H. Y., Hou, C. M., Tong, Y., Liu, Y. L., Yang, G., Liu, X. D., Yang, X., Liu, B., \& Mao, N. (2008). Identification of mesenchymal stem cells in aorta-gonad-mesonephros and yolk sac of human embryos. Blood, 111(4), 2436-2443. http://dx.doi.org/10.1182/blood-2007-07-099333. PMid:18045971.

Weiskopf, K., Schnorr, P. J., Pang, W. W., Chao, M. P., Chhabra, A., Seita, J., Feng, M., \& Weissman, I. L. (2016) Myeloid cell origins, differentiation, and clinical implications. Microbiology Spectrum, 4(5). PMid:27763252.

Weiss, M. L., Anderson, C., Medicetty, S., Seshareddy, K. B., Weiss, R. J., VanderWerff, I., Troyer, D., \& McIntosh, K. R. (2008). Immune properties of human umbilical cord wharton's jelly-derived cells. Stem Cells, 26(11), 2865-2874. http://dx.doi.org/10.1634/stemcells.2007-1028. PMid:18703664.

Wenceslau, C. V., Miglino, M. A., Martins, D. S., Ambrósio, C. E., Lizier, N. F., Pignatari, G. C., \& Kerkis, I. (2011). Mesenchymal progenitor cells from canine fetal tissues: yolk sac, liver, and bone marrow. Tissue Engineering. Part A,17(17-18), 2165-2176. http://dx.doi.org/10.1089/ten.tea.2010.0678. PMid:21529262.

Yamane, T. (2018). Mouse yolk sac hematopoiesis. Frontiers in Cell and Developmental Biology, 6, 80. http://dx.doi. org/10.3389/fcell.2018.00080. PMid:30079337.

Yamasaki, S., Nobuhisa, I., Ramadan, A., \& Taga, T. (2011). Identification of a yolk sac cell population with hematopoietic activity in view of CD45/c-Kit expression. Development, Growth \& Differentiation, 53(7), 870877. http://dx.doi.org/10.1111/j.1440-169x.2011.01293.x. PMid:21883169.

Young, P. E., Baumhueter, S., \& Lasky, L. A. (1995). The sialomucin CD34 is expressed on hematopoietic cells and blood vessels during murine development. Blood, 85(1), 96-105. http://dx.doi.org/10.1182/blood.V85.1.96. bloodjournal85196. PMid:7528578.

Zambidis, E. T., Peault, B., Park, T. S., Bunz, F., \& Civin, C. I. (2005). Hematopoietic differentiation of human embryonic stem cells progresses through sequential hematoendothelial, primitive, and definitive stages resembling human yolk sac development. Blood, 106(3), 860-870. http://dx.doi.org/10.1182/blood-2004-114522. PMid:15831705.

Zohn, I. E., \& Sarkar, A. A. (2010). The visceral yolk sac endoderm provides for absorption of nutrients to the embryo during neurulation. Birth Defects Research. Part A, Clinical and Molecular Teratology, 88(8), 593-600. http://dx.doi.org/10.1002/bdra.20705. PMid:20672346. 